Supplement of

\title{
Application of chemical derivatization techniques combined with chemical ionization mass spectrometry to detect stabilized Criegee intermediates and peroxy radicals in the gas phase
}

Alexander Zaytsev et al.

Correspondence to: Alexander Zaytsev (zaytsev@g.harvard.edu) and Frank N. Keutsch (keutsch@seas.harvard.edu)

The copyright of individual parts of the supplement might differ from the article licence. 


\section{Updated Kinetics Data for Acetone Oxide $\left(\mathrm{CH}_{3}\right)_{2} \mathrm{COO}$}

Acetone oxide $\left(\mathrm{CH}_{3}\right)_{2} \mathrm{COO}$ and acetone are formed via ozonolysis of TME, while only a certain fraction of CIs is thermally stabilized:

$\mathrm{C}_{6} \mathrm{H}_{12}+\mathrm{O}_{3} \rightarrow \phi\left(\mathrm{CH}_{3}\right)_{2} \mathrm{COO}+(1-\phi)\left(\mathrm{CH}_{3}\right)_{2} \mathrm{COO} *+\mathrm{C}_{3} \mathrm{H}_{6} \mathrm{O}$

5 where $\phi=0.32$ is the yield of SCIs for this reaction (Newland et al., 2015), non-stabilized CI is marked with an asterisk. $\mathrm{SCI}$ can in turn decompose to form a peroxy radical and $\mathrm{OH}$ :

$\left(\mathrm{CH}_{3}\right)_{2} \mathrm{COO} \stackrel{k_{2}}{\rightarrow} \mathrm{CH}_{3} \mathrm{C}(=0) \mathrm{CH}_{2} \mathrm{OO}+\mathrm{OH}$

where $k_{2}=305 \mathrm{~s}^{-1}$ (Chhantyal-Pun et al., 2016).

It can also undergo bimolecular reactions with trace gases:

$10 \quad\left(\mathrm{CH}_{3}\right)_{2} \mathrm{COO}+\mathrm{H}_{2} \mathrm{O} \stackrel{k_{3}}{\rightarrow}$ products

$\left(\mathrm{CH}_{3}\right)_{2} \mathrm{COO}+\left(\mathrm{CH}_{3}\right)_{2} \mathrm{COO} \stackrel{k_{4}}{\rightarrow}$ products

where $k_{3}=1 \times 10^{-17} \mathrm{~cm}^{3}$ molecule ${ }^{-1} \mathrm{~s}^{-1}$ (Long et al., 2018), $k_{4}=6 \times 10^{-10} \mathrm{~cm}^{3}$ molecule $\mathrm{s}^{-1}$ (Chhantyal-Pun et al., 2016).

\section{Reactivity of the spin trap DMPO with stabilized Criegee intermediates}

15 The reactivity of DMPO with SCIs in the gas phase was estimated indirectly. We conducted TME ozonolysis experiments in which we varied the amount of TME and the spin trap DMPO. In each experiment we detected SCI-DMPO adducts and estimated the mixing ratio of these species using the mass spectrometric voltage scanning procedure based on collisioninduced dissociation (Table S1). We calculated amounts of formed SCI-DMPO adducts in these experiments as a function of the reaction rate coefficient $k_{\mathrm{SCI}+\mathrm{DMPO}}$ using the MCM-based kinetic model with updated data from the literature (solid lines

20 on Fig. S1). Our experimental data (circles on Fig. S1) determines the value for this coefficient $k_{\text {SCI+DMPO }}=6 \times 10^{-11} \mathrm{~cm}^{3}$ molecule $\mathrm{e}^{-1} \mathrm{~s}^{-1}$, which is a factor of 5 lower than the collisional limit of typical atmospheric reactions. The observed amount of SCI-DMPO is likely underestimated due to wall losses in the experimental setup and inside the CIMS instrument, which gives the lower limit for $k_{\mathrm{CI}+\mathrm{DMPO}}$. This result underlines high reactivity of non-radical spin traps, such as DMPO, with stabilized Criegee intermediates. 


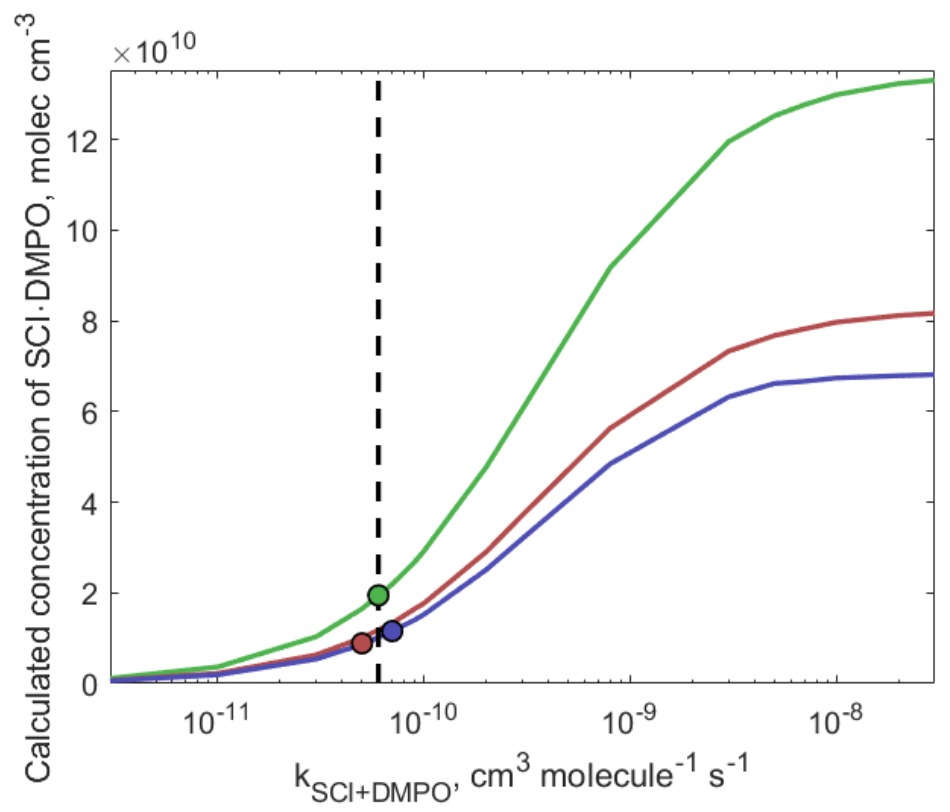

Figure S1: Calculated concentrations of SCI-DMPO adducts in various TME ozonolysis experiments as a function of the reaction rate coefficient $\boldsymbol{k}_{\mathrm{SCI}+\mathrm{DMPO}}$ (solid lines) and observed concentrations of SCI-DMPO adducts in each experiment (circles). $k_{\text {SCI+DMPO }}=6 \times 10^{-11} \mathrm{~cm}^{3}$ molecule ${ }^{-1} \mathrm{~s}^{-1}$ gives the lower limit for the reaction rate constant (dashed line). Reactant 5 concentrations in different experiments are $[\mathrm{TME}]=(1.11-8.61) \times 10^{12} ;\left[\mathrm{O}_{3}\right]=5.41 \times 10^{12} ;[\mathrm{DMPO}]=(1.05-$ 2.09) $\times 10^{13}$ molecule $\mathrm{cm}^{-3}$.

\section{Additional Table and Figures}

Table S1: Estimated $\mathrm{NH}_{4}{ }^{+}$CIMS sensitivity factors for DMPO adducts with CIs and $\mathrm{RO}_{2}$ species detected in TME and $\alpha$-pinene ozonolysis experiments. The maximum sensitivity of $\mathrm{NH}_{4}{ }^{+}$CIMS was experimentally determined in each experiment and depends on operational conditions. During spin trapping experiments with DMPO the maximum instrument sensitivity was 12,000 ndcps/ppb.

\begin{tabular}{lllc} 
Species & Ion formula & $m / z$ & Estimated sensitivity factor \\
\hline $\mathrm{C}_{3}$-SCI-DMPO & $\mathrm{C}_{9} \mathrm{H}_{17} \mathrm{NO}_{3} \mathrm{NH}_{4}^{+}$ & 205.155 & 0.2 \\
$\mathrm{C}_{3}-\mathrm{RO}_{2} \cdot \mathrm{DMPO}$ & $\mathrm{C}_{9} \mathrm{H}_{16} \mathrm{NO}_{4} \mathrm{NH}_{4}^{+}$ & 220.142 & 0.17 \\
$\mathrm{C}_{10}$-SCI-DMPO & $\mathrm{C}_{16} \mathrm{H}_{27} \mathrm{NO}_{4} \mathrm{NH}_{4}{ }^{+}$ & 315.228 & 0.2 \\
$\mathrm{C}_{10}-\mathrm{RO}_{2} \cdot \mathrm{DMPO}$ & $\mathrm{C}_{16} \mathrm{H}_{26} \mathrm{NO}_{5} \mathrm{NH}_{4}^{+}$ & 330.216 & 0.5 \\
\hline
\end{tabular}

Table S2: Descriptions of ozonolysis experiments with HFA

Olefin Initial olefin $\mathrm{O}_{3}$ concentration, HFA concentration, Calculated amount concentration, molecule $\mathrm{cm}^{-3} \quad$ molecule $\mathrm{cm}^{-3} \quad$ of reacted olefin, $\%$ molecule $\mathrm{cm}^{-3}$

\begin{tabular}{lllll}
\hline TME & $1.85 \cdot 10^{12}$ & $1.67 \cdot 10^{13}$ & $6.09 \cdot 10^{15}$ & $17 \%$
\end{tabular}




\begin{tabular}{|c|c|c|c|c|}
\hline isoprene & $1.23 \cdot 10^{13}$ & $3.20 \cdot 10^{14}$ & $5.35 \cdot 10^{15}$ & $6 \%$ \\
\hline pentene & $4.18 \cdot 10^{13}$ & $6.15 \cdot 10^{13}$ & $5.35 \cdot 10^{15}$ & $14 \%$ \\
\hline hexene & $2.21 \cdot 10^{13}$ & $2.95 \cdot 10^{14}$ & $5.35 \cdot 10^{15}$ & $50 \%$ \\
\hline$\alpha$-pinene & $2.70 \cdot 10^{12}$ & $3.20 \cdot 10^{14}$ & $5.35 \cdot 10^{15}$ & $37 \%$ \\
\hline limonene & $2.10 \cdot 10^{12}$ & $3.45 \cdot 10^{14}$ & $5.35 \cdot 10^{15}$ & $67 \%$ \\
\hline
\end{tabular}

Table S3: Descriptions of ozonolysis experiments with HFA

Olefin Initial olefin $\mathrm{O}_{3}$ concentration, DMPO concentration, Calculated amount of concentration, molecule $\mathrm{cm}^{-3} \quad$ molecule $\mathrm{cm}^{-3} \quad$ reacted olefin, $\%$ molecule $\mathrm{cm}^{-3}$

\begin{tabular}{lcccc}
\hline TME & $3.69 \cdot 10^{11}$ & $7.87 \cdot 10^{12}$ & $2.01 \cdot 10^{12}$ & $43 \%$ \\
$\alpha$-pinene & $4.92 \cdot 10^{11}$ & $1.03 \cdot 10^{13}$ & $1.10 \cdot 10^{13}$ & $9 \%$ \\
\hline
\end{tabular}
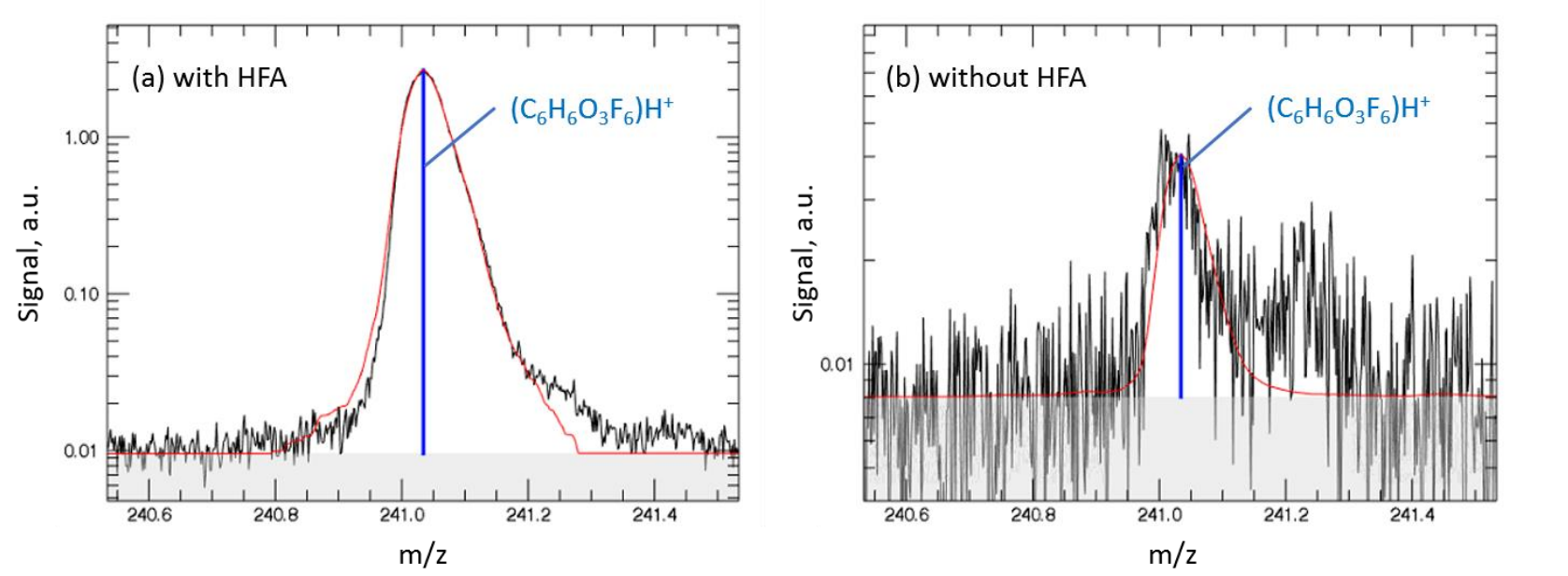

15 Figure S2: High resolution mass spectral peaks around $\mathbf{m} / \mathbf{z} 241$ obtained during the ozonolysis experiments of TME in the presence (a) and absence (b) of HFA. The blue peak $\left(\mathrm{C}_{6} \mathrm{H}_{6} \mathrm{O}_{3} \mathrm{~F}_{6} \cdot \mathrm{H}^{+}, \mathrm{m} / \mathrm{z} 241.03\right)$ is observed in the presence of $\mathrm{HFA}$. The red line is the individual fitted peak; background is shown in gray. 


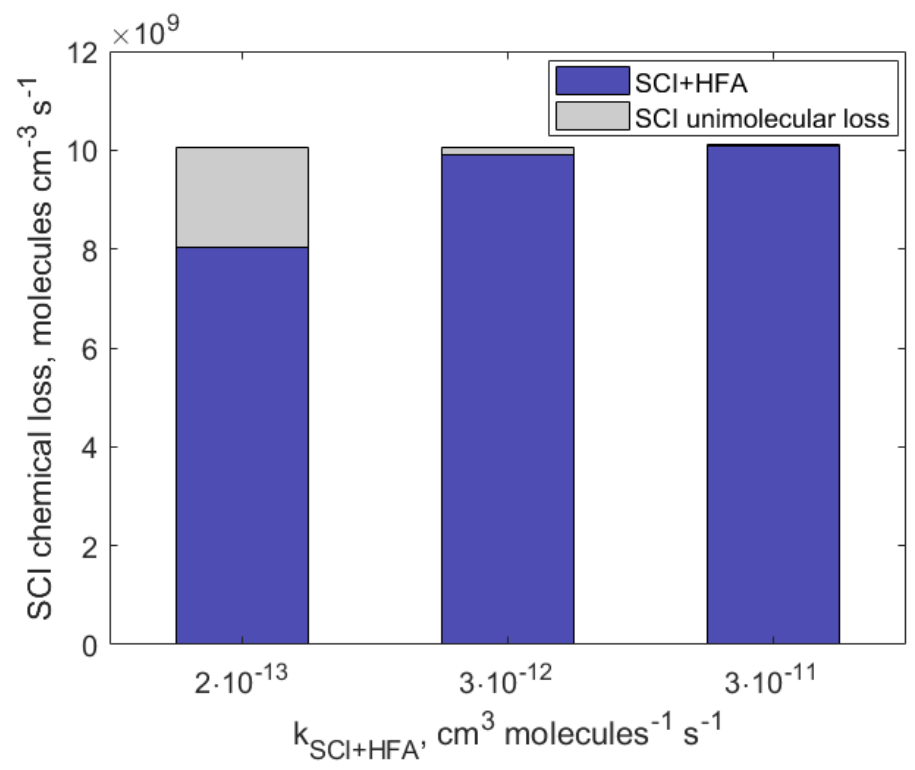

Figure S3: Chemical losses of stabilized Criegee intermediates $\left(\mathrm{CH}_{3}\right)_{2} \mathrm{COO}$ calculated assuming different $\boldsymbol{k}_{\mathrm{SCI}+\mathrm{HFA}}$ reaction rates under experimental conditions. $\boldsymbol{k}_{\mathrm{SCI}+\mathrm{HFA}}=3 \times 10^{-11} \mathrm{~cm}^{3}$ molecule $\mathrm{s}^{-1}$ corresponds to the rate constant for $\mathrm{CH}_{2} \mathrm{OO}+\mathrm{HFA}^{-1}$

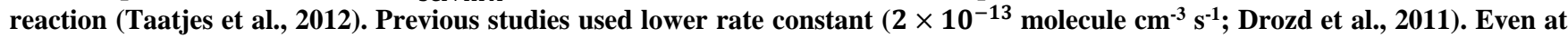
lower values of the reaction rate the major chemical loss pathway for SCI is the reaction with HFA.

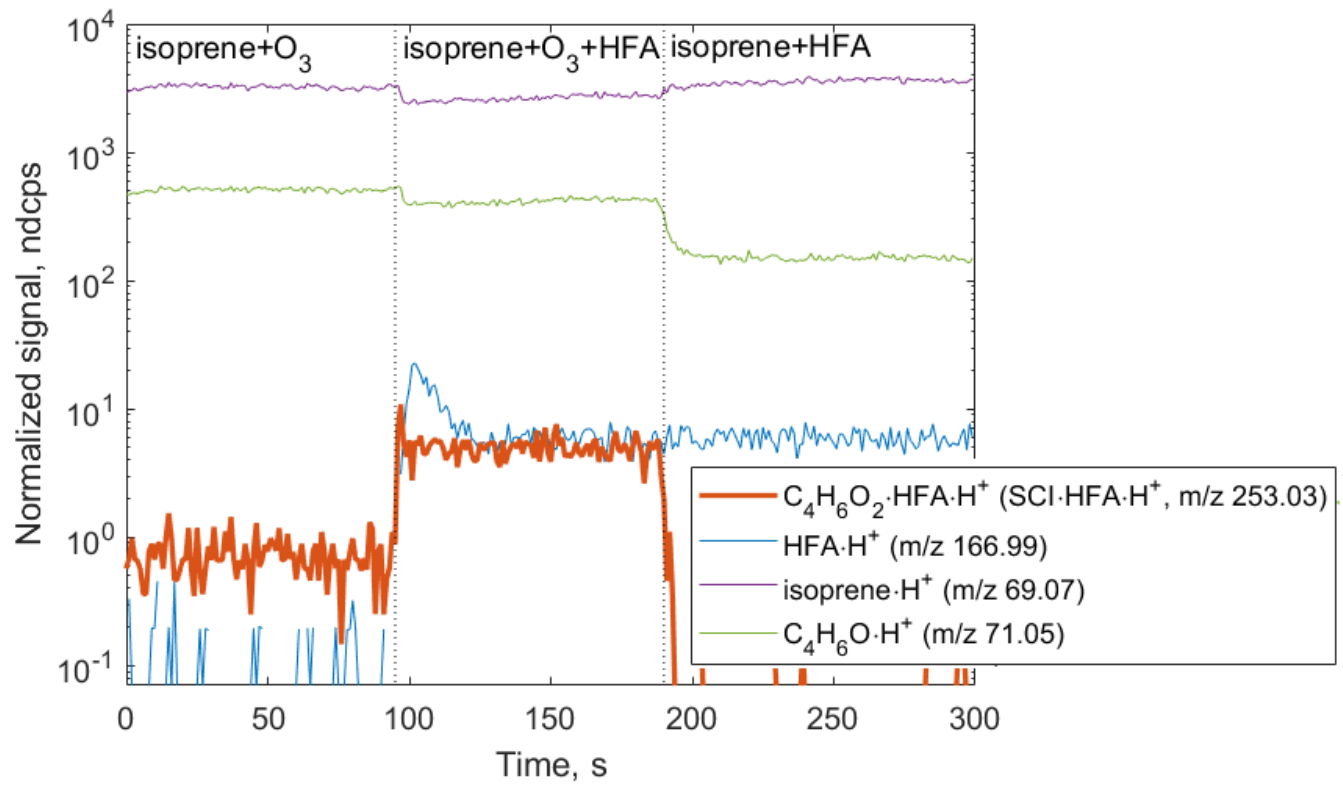

Figure S4: Ion tracers observed in an isoprene ozonolysis experiment as a function of different reactant conditions. Reactant concentrations are $[$ isoprene $\left.]=1.23 \times 10^{13} ;\left[\mathrm{O}_{3}\right]=3.20 \times 10^{14} ; \mathrm{HFA}\right]=5.35 \times 10^{15} \mathrm{molecule}^{-3}$. 


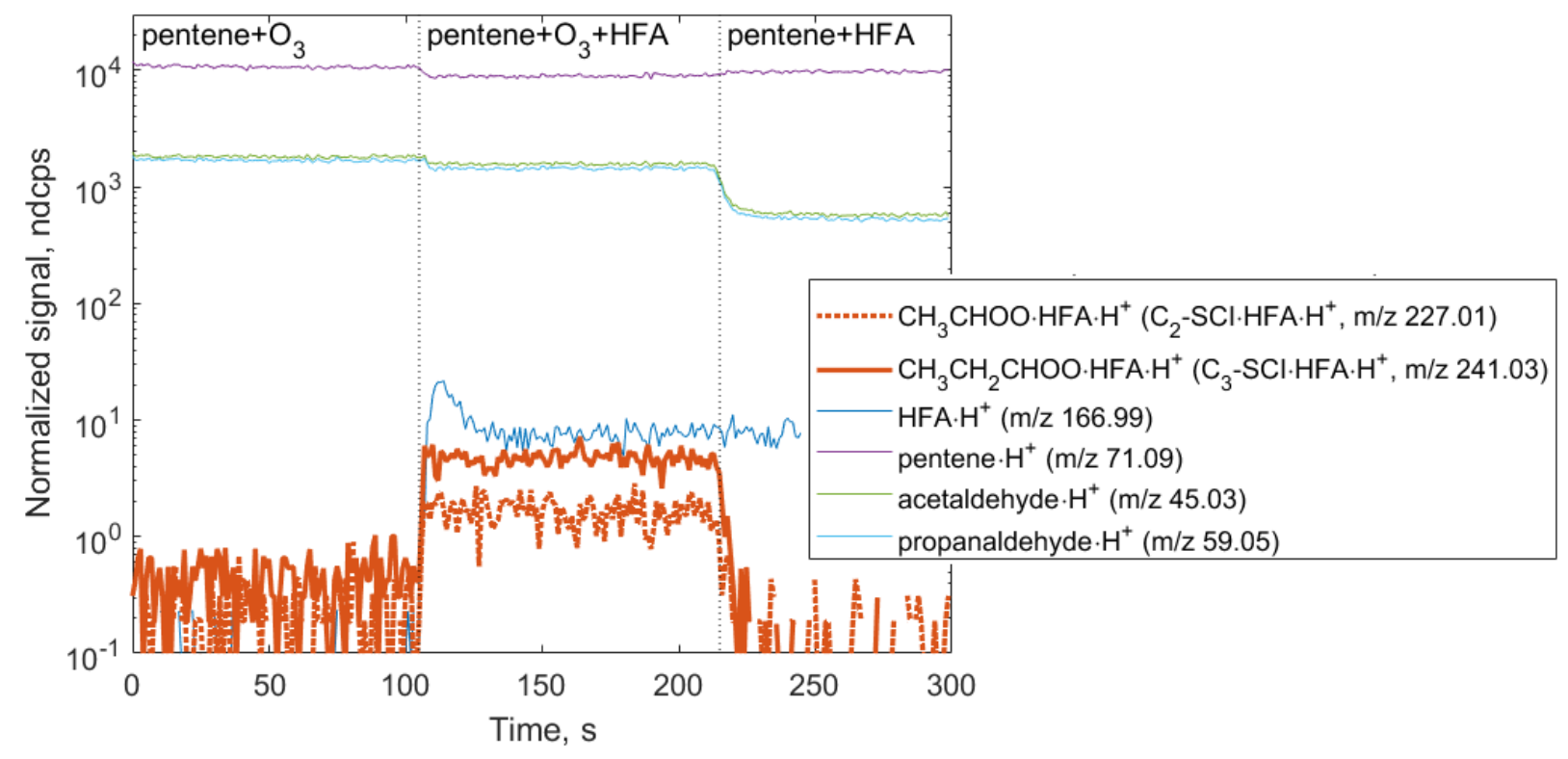

Figure S5: Ion tracers observed in a pentene ozonolysis experiment as a function of different reactant conditions. Reactant concentrations are $[$ pentene $]=4.18 \times 10^{13} ;\left[\mathrm{O}_{3}\right]=6.15 \times 10^{13} ;[\mathrm{HFA}]=5.35 \times 10^{15} \mathrm{molecule}^{-3}$.

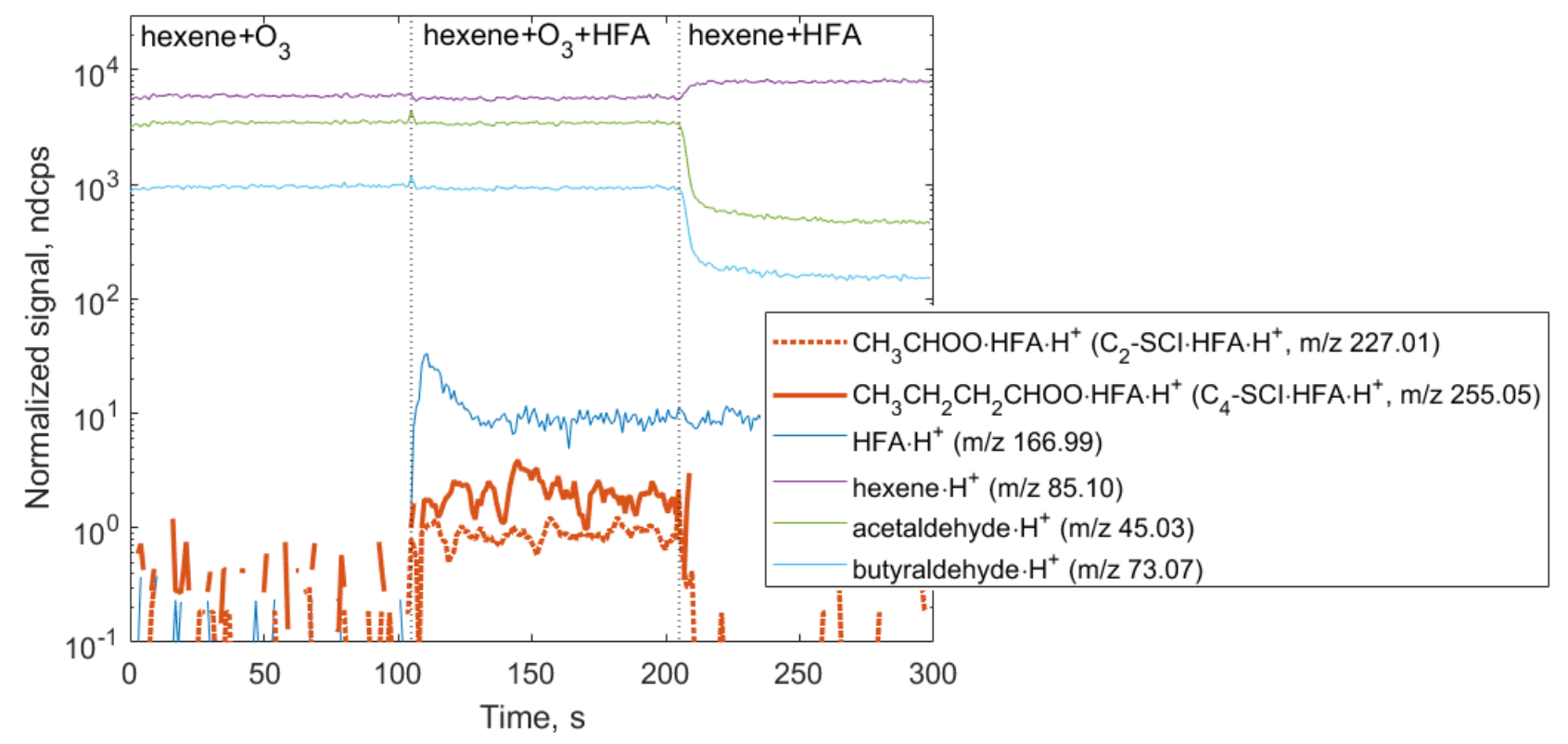

5 Figure S6: Ion tracers observed in a hexene ozonolysis experiment as a function of different reactant conditions. Reactant

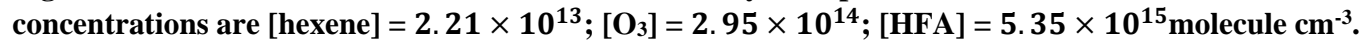




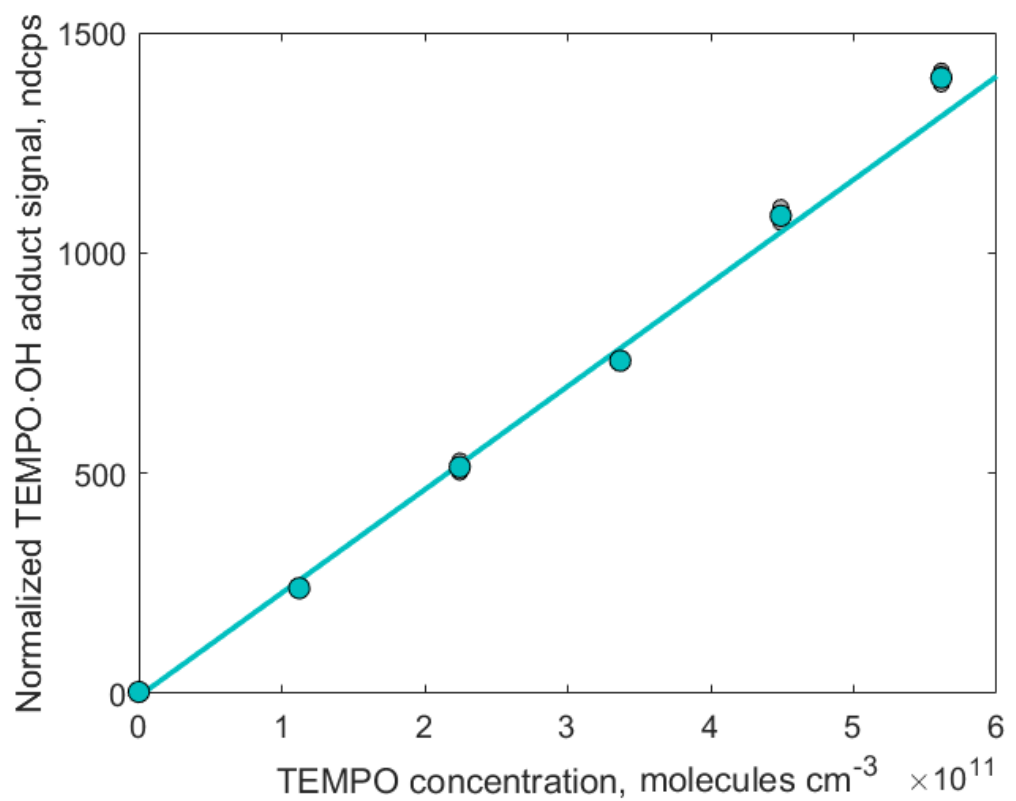

Figure S7: TEMPO $\cdot \mathrm{OH}$ adduct signal $\left(\mathrm{C}_{9} \mathrm{H}_{18} \mathrm{NO} \cdot \mathrm{H}^{+}, \mathrm{m} / z\right.$ 174.149), measured by $\mathrm{H}_{3} \mathrm{O}^{+} \mathrm{CIMS}$, as a function of $\mathrm{TEMPO}$ concentration.

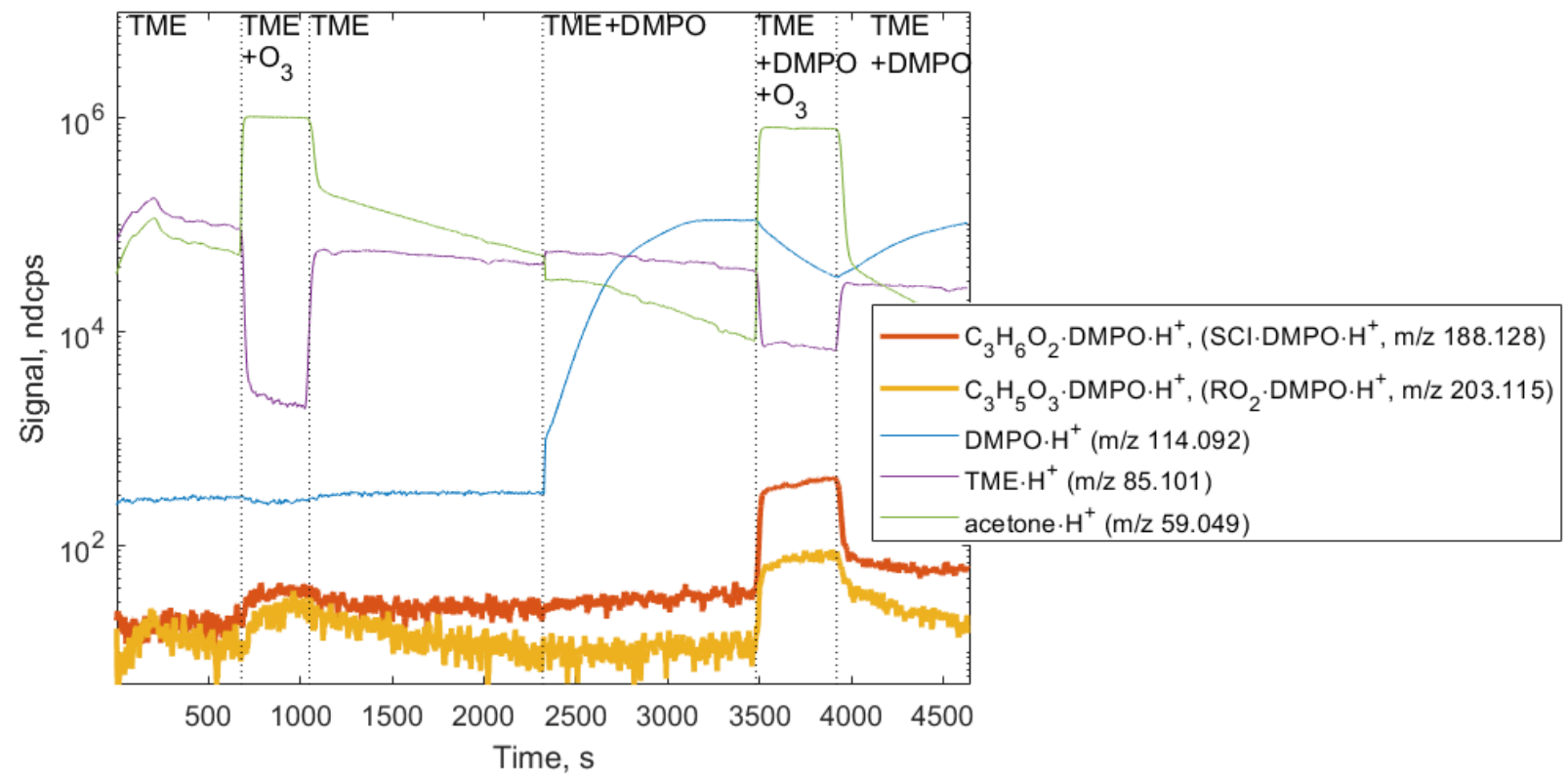

5 Figure S8: Ion tracers observed by $\mathrm{H}_{3} \mathrm{O}^{+} \mathrm{CIMS}$ in a TME ozonolysis experiment as a function of different reactant conditions. Reactant concentrations are $[\mathrm{TME}]=4.92 \times 10^{11} ;\left[\mathrm{O}_{3}\right]=1.89 \times 10^{13} ;[\mathrm{DMPO}]=1.27 \times 10^{12} \mathrm{molecule}^{-3}$. 


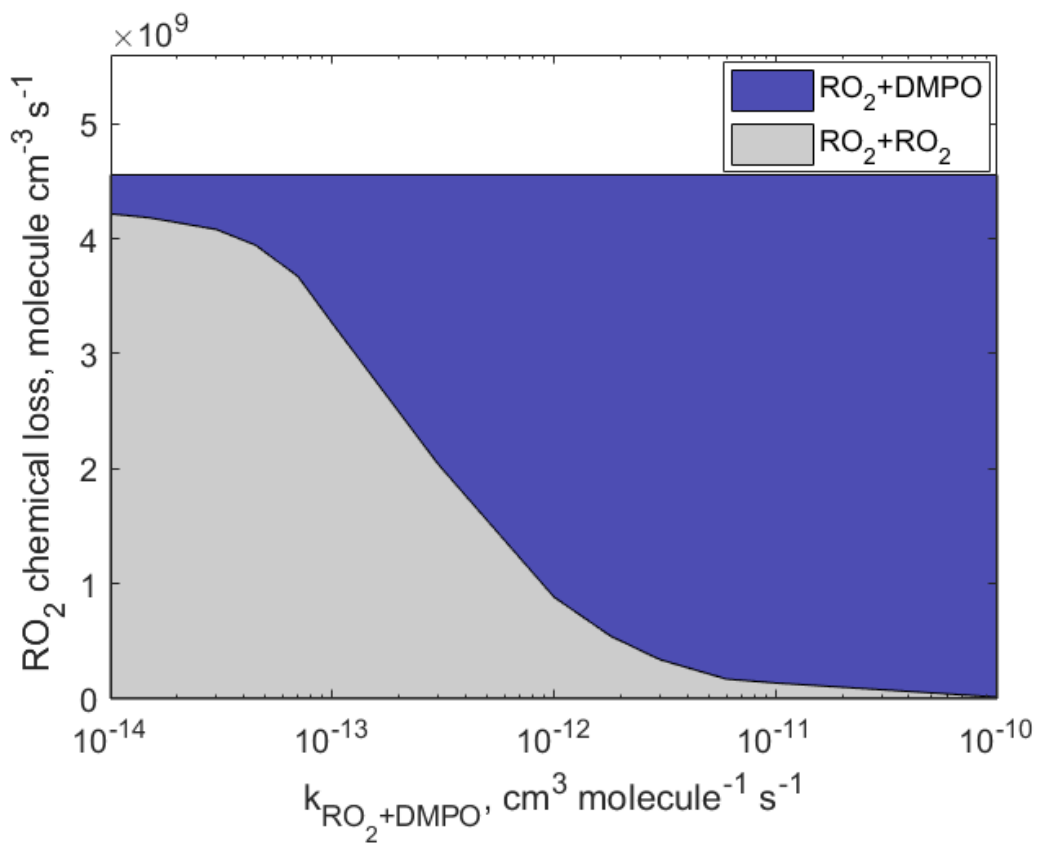

Figure S9: Chemical loss of organic peroxy radicals $\mathrm{CH}_{3} \mathrm{C}(=\mathrm{O}) \mathrm{CH}_{2} \mathrm{OO}$ calculated assuming different $\boldsymbol{k}_{\mathrm{RO}}+\mathrm{DMPO}_{2}$ reaction rates under experimental conditions.

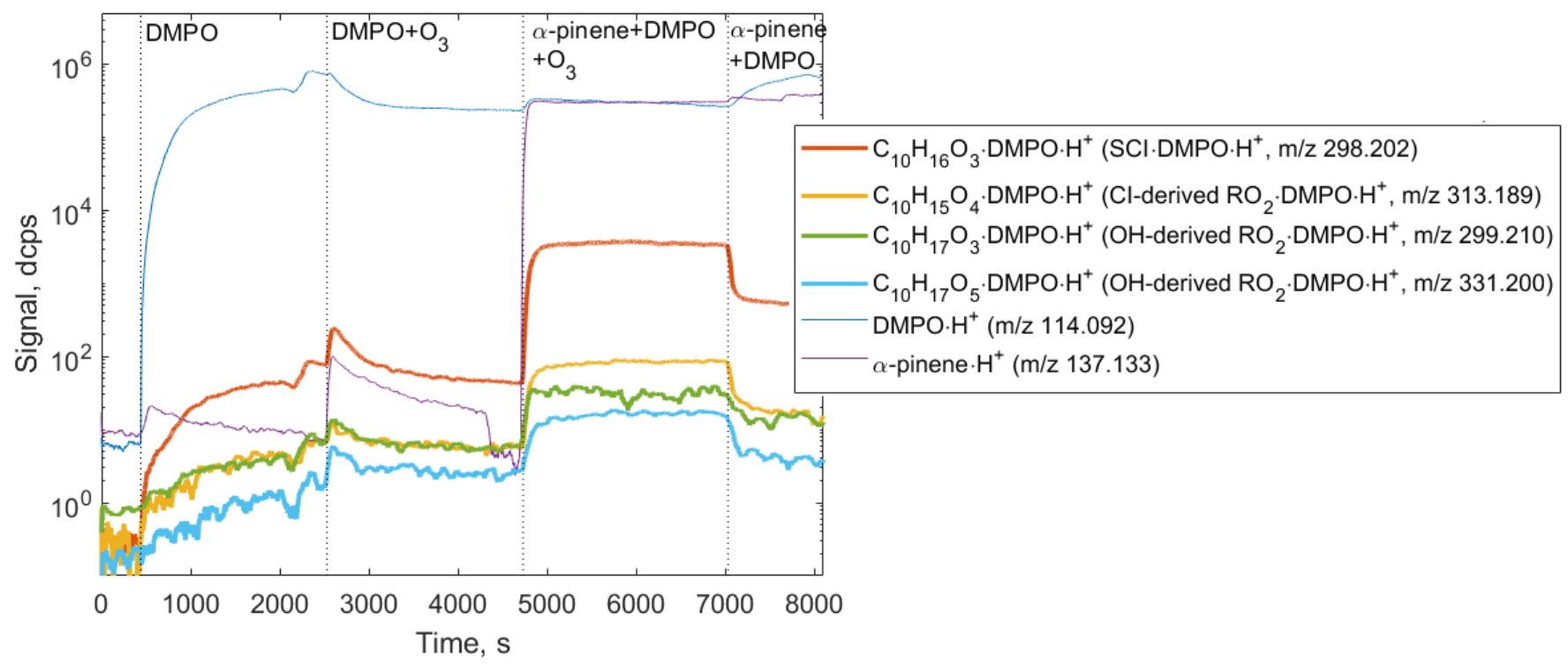

Figure S10: Ion tracers observed by $\mathrm{H}_{3} \mathrm{O}^{+} \mathrm{CIMS}$ in an $\alpha$-pinene ozonolysis experiment as a function of different reactant conditions. Reactant concentrations are $[\alpha$-pinene $]=4.92 \times 10^{11} ;\left[\mathrm{O}_{3}\right]=1.03 \times 10^{13} ;[\mathrm{DMPO}]=1.10 \times 10^{13} \mathrm{molecule}^{-3}$. 


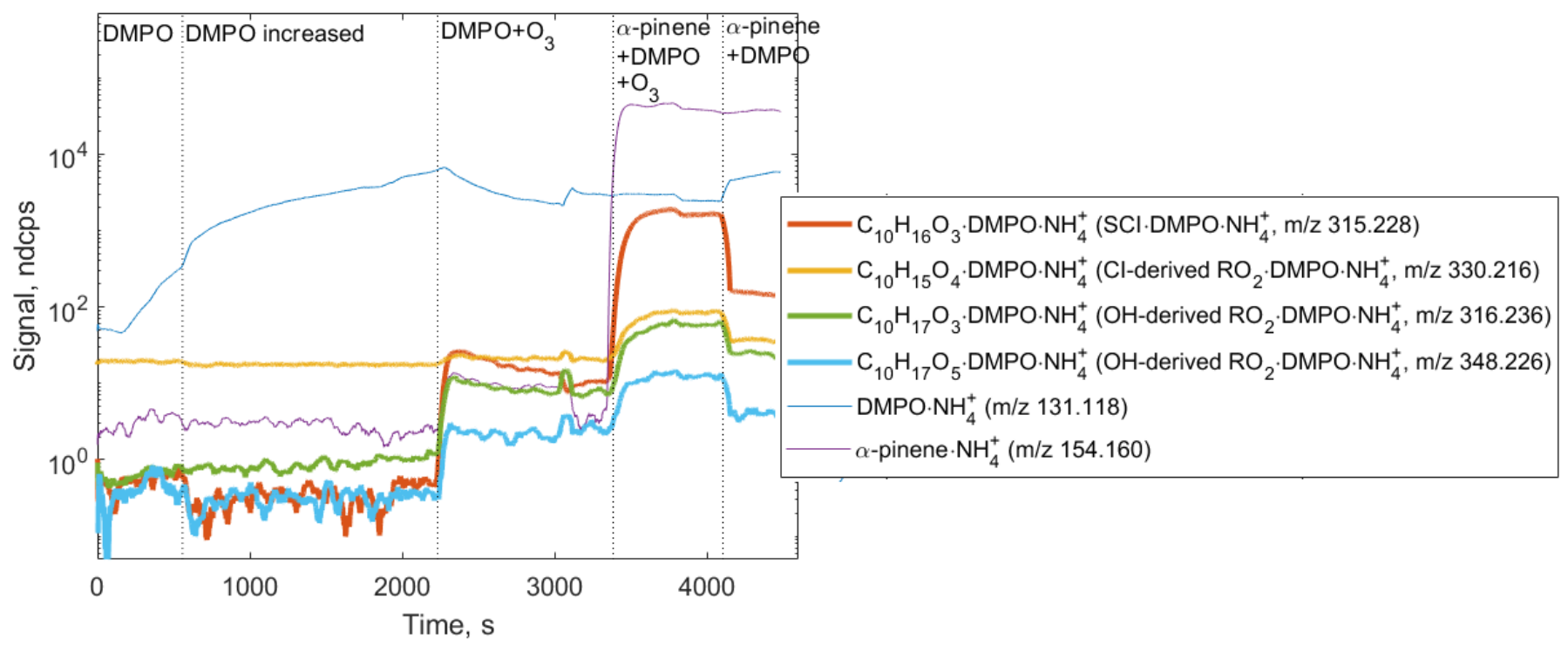

Figure S11: Ion tracers observed by $\mathrm{NH}_{4}^{+}$CIMS in an $\alpha$-pinene ozonolysis experiment as a function of different reactant conditions. Reactant concentrations are $[\alpha$-pinene $]=4.92 \times 10^{11} ;\left[O_{3}\right]=1.03 \times 10^{13} ;[D M P O]=1.10 \times 10^{13} \mathrm{molecule}^{-3}$.

\section{References}

5 Chhantyal-Pun, R., Welz, O., Savee, J.D., Eskola, A.J., Lee, E.P.F., Blacker, L., Hill, H.R., Ashcroft, M., Khan, M.A.H., Lloyd-Jones, G.C., Evans, L., Rotavera, B., Huang, H., Osborn, D.L., Mok, D.K.W., Dyke, J.M., Shallcross, D.E., Percival. C.J., Orr-Ewing, A.J., and Taatjes, C.A.: Direct Measurements of Unimolecular and Bimolecular Reaction Kinetics of the Criegee Intermediate $\left(\mathrm{CH}_{3}\right)_{2} \mathrm{COO}$, J. Phys. Chem. A, 121, 4-15, DOI: 10.1021/acs.jpca.6b07810, 2016.

Long, B., Bao, J.L., and Truhlar, D.G. Unimolecular reaction of acetone oxide and its reaction with water in the atmosphere,

10 PNAS, 115, 6135-6140, DOI: 10.1073/pnas.1804453115, 2018.

Newland, M. J., Rickard, A. R., Sherwen, T., Evans, M. J., Vereecken, L., Muñoz, A., Ródenas, M., and Bloss, W. J.: The atmospheric impacts of monoterpene ozonolysis on global stabilised Criegee intermediate budgets and $\mathrm{SO}_{2}$ oxidation: experiment, theory and modelling, Atmos. Chem. Phys., 18, 6095-6120, DOI: 10.5194/acp-18-6095-2018, 2018. 